\title{
PENERAPAN MODEL PEMBELAJARAN KOOPERATIF DENGAN BANTUAN INQUIRY BASED LEARNING UNTUK MENINGKATKAN PRESTASI SISWA PADA MATA PELAJARAN KONSTRUKSI BANGUNAN KELAS X SMK NEGERI 1 GENENG
}

\author{
Rahmat Fajar Asrofin ${ }^{1}$, Sri Sumarni ${ }^{2}$, Sukatiman ${ }^{3}$ \\ Pendidikan Teknik Bangunan, Universitas Sebelas Maret \\ e-mail: rahmatfajar52@gmail.com
}

\begin{abstract}
Abstrak: Tujuan penelitian ini adalah untuk mengetahui: (1) Peningkatan prestasi siswa mata pelajaran Konstruksi Bangunan kelas X TGB 1 SMK Negeri 1 Geneng; (2) Efektifitas inquiry based learning untuk meningkatkan prestasi belajar. Penelitian ini merupakan penelitian tindakan kelas yang dilaksanakan di kelas X TGB 1 yang berjumlah 33 siswa. Validitas data menggunakan isi dan konstruk sedangkan analisa data menggunakan analisis interaktif. Hasil penelitian menunjukkan bahwa penggunaan model pembelajaran kooperatif dengan bantuan inquiry based learning dapat memperbaiki dan meningkatkan prestasi siswa ditinjau dari tahap prasiklus sampai tahap siklus II. Hasil pra siklus ranah afektif 6,06\%, siklus 1 ranah afektif 36,36\% dan pada siklus 2 sebesar 84,85\%. Hasil pra siklus ranah psikomotor 3,03\%, siklus 1 48,48\% dan pada siklus 2 sebesar 87,88\%. Hasil pra siklus ranah kognitif 33,33\%, siklus 1 60,61\% dan pada siklus 2 sebesar 75,76\%. Ketuntasan prestasi siswa siklus 1 sebesar 24,24\% dan siklus 2 sebesar 75,75\%. Hal ini menunjukkan bahwa terjadi peningkatan prestasi siswa.
\end{abstract}

Kata kunci: Inquiry Based Learning.

${ }^{1}$ Mahasiswa Program Studi Pendidikan Teknik Bangunan FKIP UNS

${ }^{2}$ Pembimbing I Sri Sumarni, S.T., M.T..

${ }^{3}$ Pembimbing II Sukatiman, S.T.,M.Si. 


\title{
APPLICATION OF COOPERATIVE LEARNING MODEL WITH HELP OF INQUIRY BASED LEARNING TO IMPROVE STUDENTS' ACHIEVEMENT IN BUILDING CONSTRUCTION SUBJECT IN CLASS X SMK NEGERI 1 GENENG
}

\author{
Rahmat Fajar Asrofin ${ }^{1}$, Sri Sumarni ${ }^{2}$, Sukatiman ${ }^{3}$ \\ Pendidikan Teknik Bangunan, Universitas Sebelas Maret \\ e-mail: rahmatfajar52@gmail.com
}

\begin{abstract}
The purpose of this research aims to determine: (1) improvement of students' achievement in building construction subject in class X TGB 1 SMK Negeri 1 Geneng; (2) Effectiveness of inquiry based learning to improve learning achievement. This research is a classroom action research conducted in class $X$ TGB 1, participant to 33 students. Test validity of the data used the content and construct validity and data analysis used interactive analysis. The results showed that the application of cooperative learning model based on inquiry learning could enhanced and improved students' achievement outcomes. In terms of pre cycle to the second cycle. The result pre-cycle of affective was $6.06 \%$, affective increased from $36.36 \%$ in first cycle to $84.85 \%$ in second cycle. The result pre-cycle of psychomotor $3.03 \%$, $48.48 \%$ in first cycle increased to $87.88 \%$ in second cycle. The result pre-cycle of cognitive was $33.33 \%, 60.61 \%$ in first cycle increased to $75.76 \%$ in second cycle. Students' achievement completeness in first cycle was $24.24 \%$ and $75.75 \%$ in second cycle. This research showed that cooperative learning model based on inquiry based learning can increase students' achievement.
\end{abstract}

Keywords: Inquiry Based Learning.

${ }^{1}$ Mahasiswa Program Studi Pendidikan Teknik Bangunan FKIP UNS

${ }^{2}$ Pembimbing I Sri Sumarni, S.T., M.T..

${ }^{3}$ Pembimbing II Sukatiman, S.T.,M.Si. 


\section{PENDAHULUAN}

$\begin{array}{ll} & \text { Penanaman disiplin belajar } \\ \text { siswa dapat dilakukan dengan }\end{array}$ beberapa pembelajaran di kelas. Penentuan model pembelajaran merupakan hal yang teramat penting serta membutuhkan suatu inovasi atau terobosan dalam menyampaikan materi ajar oleh guru sebagai proses transformasi ilmu pengetahuan. Banyak upaya yang telah dilakukan untuk meningkatkan aktivitas belajar siswa dan dari itu semua telah banyak kesuksesan yang dicapai, namun dengan berbagai kesuksesan itu belum sepenuhnya memuaskan bagi pendidik dan orang tua, hal ini menuntut suatu pemikiran serta kerja keras untuk memecahkan masalah yang ada pada pembelajaran.

Berdasarkan pengamatan oleh penulis di kelas X TGB 1 Sekolah Menengah Kejuruan Negeri 1 Geneng (X TGB 1 SMK Negeri 1 Geneng) tahun pelajaran 2015/2016 untuk mata pelajaran produktif Konstruksi Bangunan berkaitan dengan prestasi siswa dalam pembelajaran rendah, karena masih dijumpai masalah masalah antara lain pendidik (guru) masih sebagai pusat kegiatan belajar mengajar dan siswa hanya memperoleh informasi dari mencatat materi ajar dari guru.

Masalah seperti yang dialami siswa tidak aktif, kurang antusias dan kurang semangat dalam pembelajaran memerlukan solusi agar tidak terus menerus terjadi, sehingga siswa dapat mencapai prestasi belajar yang maksimal.

Menyikapi permasalahan tersebut, maka perlu dilakukan penerapan model pembelajaran yang baru sebagai upaya dalam memecahkan masalah. Pada penelitian ini digunakan model pembelajaran kooperatif dengan bantuan Inquiry Based Learning. Model pembelajaran tersebut dalam pelaksanaannya mengkondisikan siswa belajar berkelompok, sehingga menuntut siswa untuk lebih berperan secara aktif dalam proses pembelajaran.

\section{Pembelajaran Kooperatif}

Menurut Slavin (dalam Isjoni, 2009: 15) adalah suatu model pembelajaran di mana dalam sistem belajar dan bekerja dalam kelompokkelompok kecil yang berjumlah 4-6 orang secara kolaboratif sehingga dapat merangsang siswa lebih bergairah dalam belajar. Bukan untuk membantu guru menyampaikan materi penuh kepada siswa, melainkan membantu siswa untuk lebih mengembangkan ketrampilan berfikir. Menurut Tom V. Savage (dalam Rusman, 2012:203) yaitu suatu pendekatan yang menekankan kerja sama dalam kelompok.

${ }^{1}$ Mahasiswa Program Studi Pendidikan Teknik Bangunan FKIP UNS

${ }^{2}$ Pembimbing I Sri Sumarni, S.T., M.T.

${ }^{3}$ Pembimbing II Sukatiman, S.T.,M.Si. 
Ciri-ciri Model pembelajaran

Kooperatif Hamdani (2011: 31) mengungkapkan model pembelajaran kooperatif memiliki ciri sebagai berikut :

1) Setiap anggota memiliki peran.

2) Terjadi hubungan interaksi langsung diantara siswa.

3) Setiap anggota kelompok bertanggung jawab atas cara belajarnya dan juga teman-teman sekelompoknya.

4) Guru membantu mengembangkan keterampilan-keterampilan interpersonal kelompok.

5) Guru hanya berinteraksi dengan kelompok saat diperlukan.

\section{Pembelajaran Inquiry Based Learning}

Hamruni (2012: 88) Inquiry Based Learning adalah rangkaian kegiatan pembelajaran yang menekankan pada proses berfikir secara kritis dan analisis untuk mencari dan menemukan sendiri jawaban dari suatu masalah yang dipertanyakan.

Ciri-ciri Inquiry Based Learning menurut Hamruni (2012: 9)
1) Percaya diri terhadap kemampuan belajarnya.

2) Senang saat berusaha memecahkan masalah.

3) Percaya pada penilaian sendiri dan tidak sekedar bergantung pada penilaian orang lain maupun lingkungan.

4) Tidak takut menjadi salah.

5) Tidak ragu dalam menjawab.

6) Fleksibilitas pandangan.

7) Menghargai fakta dan mampu membedakan antara fakta dan opini.

8) Tidak merasa perlu mendapat jawaban final untuk semua pertanyaan dan lebih merasa nyaman saat tidak mengetahui jawaban dari pertanyaan sulit daripada sekedar menerima jawaban yang terlalu disederhanakan.

\section{Belajar dan Prestasi Belajar}

Suryabrata dalam Hamzah B. Uno (2015: 138) belajar adalah suatu proses yang dilakukan dengan sengaja untuk memperoleh pengetahuan, kecakapan, dan pengalaman baru ke arah yang lebih baik. Proses belajar terjadi apabila terdapat perubahan dalam hal kesiapan pada diri seseorang

${ }^{1}$ Mahasiswa Program Studi Pendidikan Teknik Bangunan FKIP UNS

${ }^{2}$ Pembimbing I Sri Sumarni, S.T., M.T..

${ }^{3}$ Pembimbing II Sukatiman, S.T.,M.Si. 
dalam berhubungan dengan lingkungannya. Moh. Surya dalam Hamzah B. Uno (2015: 139) "belajar dapat diartikan sebagai suatu proses yang dilakukan oleh individu untuk memperoleh perubahan perilaku baru secara keseluruhan, sabagai hasil dari pengalaman individu itu sendiri dalam berinteraksi dengan lingkungannya". Hamdani (2011: 137) mengungkapkan prestasi adalah hasil dari suatu kegiatan yang telah dikerjakan, diciptakan, baik secara individu maupun kelompok. Prestasi belajar merupakan bukti keberhasilan yang telah dicapai oleh seseorang. Dengan demikian, prestasi belajar merupakan hasil maksimum yang yang dicapai oleh seseorang setelah melakukan usaha-usaha belajar. Wingkel dalam Hamdani (2011:138) .

Dari beberapa pengertian di atas maka dapat diambil kesimpulan bahwa prestasi belajar adalah suatu hasil yang diperoleh melalui perubahan dalam diri individu dari aktivitas belajar.

\section{Konstruksi Bangunan}

Mata pelajaran Konstruksi Bangunan merupakan salah satu mata pelajaran produktif yang diberikan kepada siswa kelas X Teknik Gambar Bangunan SMK Negeri 1 Geneng. Pada mata pelajaran Konstruksi Bangunan siswa mempelajari tentang konstruksi suatu bangunan antara lain: pengetahuan bata, konstruksi dinding batu bata dan fungsi dinding, konstruksi lengkung, konstruksi pertebalan dinding dan fungsinya.

Untuk lebih menguasai konsep tentang Konstruksi Bangunan, guru hendaknya memperlihatkan contohcontoh pekerjaan bangunan agar dapat menambah wawasan siswa terhadap pekerjaan bangunan. Dengan demikian yang menjadi tujuan pembelajaran dapat tercapai.

\section{METODE PENELITIAN}

Penelitian tindakan kelas ini dilaksanakan di SMK Negeri 1 Geneng yang beralamat di Jl. Raya Ngawi-Madiun km 12. Penelitian ini dilaksanakan di kelas untuk mata pelajaran Konstruksi Bangunan pada program keahlian Teknik Gambar Bangunan. Subjek penelitian yang diambil adalah siswa kelas X TGB 1 SMK Negeri 1 Geneng yang berjumlah 33 siswa.

Teknik pengumpulan data yang digunakan yaitu melalui wawancara, observasi, dokumentasi dan tes siswa. Sumber data dalam penelitian ini adalah guru mata pelajaran Konstruksi Bangunan dan siswa kelas X TGB 1 SMK Negeri 1 Geneng tahun pelajaran $2015 / 2016$.

\footnotetext{
${ }^{1}$ Mahasiswa Program Studi Pendidikan Teknik Bangunan FKIP UNS

${ }^{2}$ Pembimbing I Sri Sumarni, S.T., M.T..

${ }^{3}$ Pembimbing II Sukatiman, S.T.,M.Si.
} 
Validasi yang digunakan dalam penelitian tindakan ini menggunakan validasi isi dan konstruk. Validasi isi digunakan untuk penilaian hasil belajar. Validasi konstruk digunakan untuk mengobservasi (observable) dan mengukur (measurable).

Teknik analisis data yang digunakan untuk penelitian ini adalah analisis interaktif. Data yang dianalisis secara analisis interaktif yang terdiri dari reduksi data, sajian data, dan penarikan simpulan dilakukan dalam bentuk interaktif dengan pengumpulan data sebagai suatu proses siklus.

\section{Prosedur Penelitian}

Prosedur penelitian adalah serangkaian tahapan yang di tempuh dalam suatu penelitian mulai dari awal hingga akhir. Pelaksanaan penelitian tindakan ini diawali dengan tindakan pra siklus. Tindakan pra siklus ini dilakukan untuk mengetahui perkembangan sebelum adanya perencanaan tindakan.

\section{Siklus I}

mencakup:

Tahap perencanaan tindakan,

a. Meminta ijin kepada kepala sekolah dan guru mata pelajaran Konstruksi Bangunan X TGB 1 SMK Negeri 1 Geneng.

b. Observasi pra tindakan terhadap kegiatan pembelajaran di kelas $\mathrm{X}$ TGB 1. c. Identifikasi masalah yang terjadi dan menentukan alternatif pemecahan masalah.

d. Merencanakan pembelajaran yang akan diterapkan dalam proses belajar mengajar dengan menggunakan model kooperatif dengan bantuan inquiry based learning.

e. Mempersiapkan perangkat pembelajaran antara lain Silabus, RPP, Bahan Ajar, Lembar Kerja Siswa, Lembar Observasi dan Tes Siswa.

Tahap pelaksanaan tindakan, mencakup: a) Melaksanakan langkahlangkah sesuai dengan perencanaan; b) Menerapkan model pembelajaran kooperatif dengan bantuan inquiry based learning; c) Melakukan pengamatan terhadap setiap langkahlangkah pelaksanaan tindakan sesuai perencanaan.

Tahap observasi, merupakan pengamatan selama tahap pelaksanaan tindakan berlangsung yang bertujuan untuk merekam kondisi atau suasana yang ada saat penelitian dan hasil dari pelaksanaan penelitian. Kegiatan observasi ini dilakukan oleh peneliti untuk mengamati aktifitas siswa dalam pelajaran konstruksi bangunan dan untuk mengetahui apakah aktifitas siswa sudah sesuai dengan kisi-kisi penilaian dalam lembar observasi atau

\footnotetext{
${ }^{1}$ Mahasiswa Program Studi Pendidikan Teknik Bangunan FKIP UNS

${ }^{2}$ Pembimbing I Sri Sumarni, S.T., M.T..

${ }^{3}$ Pembimbing II Sukatiman, S.T.,M.Si.
} 
tidak. Sehingga hasil observasi dapat diperbaiki pada siklus berikutnya.

Tahap refleksi, merupakan tahap yang dilakukan untuk menganalisis pelaksanaan proses pembelajaran, penguasaan materi, capaian prestasi belajar dan terjadinya keaktifan siswa. Data yang diperoleh dari tindakan ini selanjutnya digunakan sebagai bahan refleksi dan evaluasi sebagai perbaikan pelaksanaan tindakan pada siklus 2

\section{Siklus II}

Hasil refleksi pada siklus 1 menjadi dasar untuk perencanaan pada siklus 2. Pelaksanaan siklus 2 merupakan tindak lanjut dari perolehan observasi serta informasi. Refleksi dilakukan berdasarkan data observasi. Hasil refleksi setiap siklus akan menjadi bahan pertimbangan siklus berikutnya, serta menjadi bahan penarikan simpulan.

\section{PEMBAHASAN}

Pra Siklus

Dari hasil observasi prasiklus ini diperoleh data sebagai berikut:

a. Untuk ranah kognitif terdapat 11 siswa yang tuntas dengan persentase ketuntasan 33,33\% , dan rata-rata nilai kelas 71,78.

b. Untuk ranah afektif terdapat 2 siswa yang tuntas dengan persentase ketuntasan $6,06 \%$, dan rata-rata nilai kelas 33,71. c. Untuk ranah psikomotor terdapat 1 siswa yang tuntas dengan persentase ketuntasan $3,03 \%$ dan rata-rata nilai kelas 38,18 .

\section{Siklus I}

Data hasil penelitian siklus 1 mengenai penerapan model pembelajaran Kooperatif dengan bantuan Inquiry based Learning di kelas X TGB 1 SMK Negeri 1 Geneng diperoleh hasil sebagai berikut:

a. Untuk ranah kognitif terdapat 20 siswa yang tuntas dengan persentase ketuntasan 60,61\%, dan rata-rata nilai kelas 72,15.

b. Untuk ranah afektif terdapat 12 siswa yang tuntas dengan persentase ketuntasan 36,36\%, dan rata-rata nilai kelas 71,66.

c. Untuk ranah psikomotor terdapat 16 siswa yang tuntas dengan persentase ketuntasan $48,48 \%$ dan rata-rata nilai kelas 73,63 .

\section{Siklus II}

Pada tindakan siklus 2 dilakukan sebagai upaya perbaikan dari hasil tindakan pada siklus 1 . Perencanaan tindakan siklus 2 dilakukan berdasarkan hasil dari capaian siklus 1. Prestasi belajar tersebut antara lain:

a. Untuk ranah kognitif terdapat 25 siswa yang tuntas dengan

${ }^{1}$ Mahasiswa Program Studi Pendidikan Teknik Bangunan FKIP UNS

${ }^{2}$ Pembimbing I Sri Sumarni, S.T., M.T..

${ }^{3}$ Pembimbing II Sukatiman, S.T.,M.Si. 
persentase ketuntasan $75,76 \%$, dan rata-rata nilai kelas 75,04.

b. Untuk ranah afektif terdapat 28 siswa yang tuntas dengan persentase ketuntasan $84,85 \%$, dan rata-rata nilai kelas 77,95 .

c. Untuk ranah psikomotor terdapat 29 siswa yang tuntas dengan persentase ketuntasan $87,88 \%$ dan rata-rata nilai kelas 80,68 .

\section{Perbandingan Hasil Belajar Ranah Kognitif}

Pemahaman siswa terhadap materi pengetahuan bata, ikatan bata dan hubungan bata yang telah dipelajari dapat diketahui dari hasil tes kognitif terlihat mengalami peningkatan mulai dari pra siklus, siklus 1 dan siklus 2. Hasil perbandingan ranah kognitif dapat dilihat pada tabel berikut:

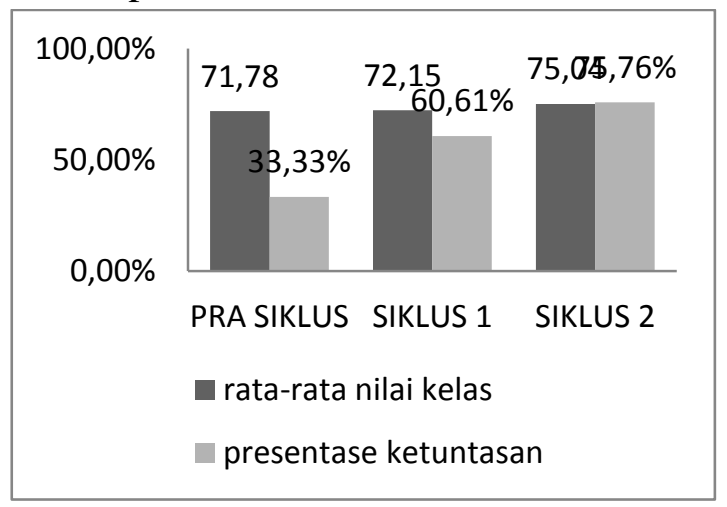

Gambar 1. Grafik Perbandingan Rata-rata

Nilai Kognitif Prasiklus, Siklus 1 dan Siklus 2

Berdasarkan grafik tersebut bahwa untuk prestasi belajar dari ranah kognitif mengalami peningkatan mulai dari prasiklus 71,78, siklus 1 yakni 72,15 dan siklus 2 yakni 75,04. Dari hasil tersebut dapat disimpulkan bahwa pemahaman siswa terhadap materi mata pelajaran Konstruksi Bangunan semakin meningkat dengan menggunakan model pembelajaran Kooperatif dengan bantuan inquiry Based Learning.

\section{Ranah Afektif}

Hasil penilaian pada ranah afektif melalui lembar observasi siswa yang diamati selama proses pembelajaran berlangsung. Hasil penilaian ini digunakan untuk mengetahui tingkat aktivitas siswa. Berikut adalah aspek yang dinilai dalam penilaian ranah afektif: a) Penerimaan; b) Tanggapan; c) Menilai; d) Tenggang rasa; e) Karakterisasi. Hasil penilaian ranah afektif untuk capaian ketuntasan dari tiap siklusnya yang digambarkan dalam grafik berikut ini:

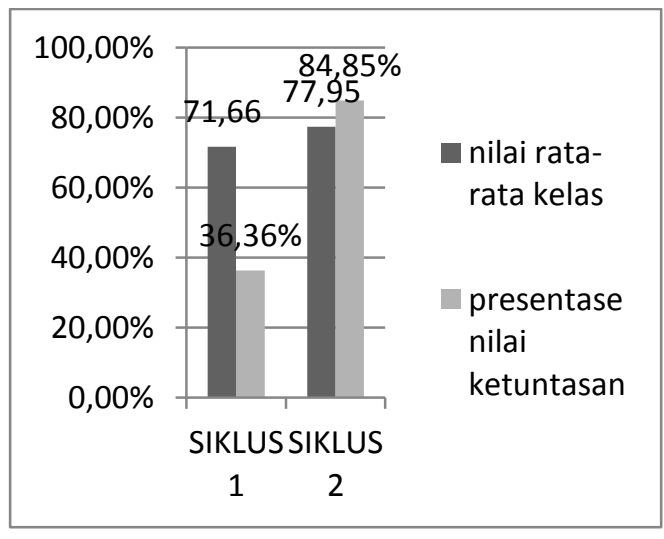

${ }^{1}$ Mahasiswa Program Studi Pendidikan Teknik Bangunan FKIP UNS

${ }^{2}$ Pembimbing I Sri Sumarni, S.T., M.T..

${ }^{3}$ Pembimbing II Sukatiman, S.T.,M.Si. 
Gambar 2. Grafik Perbandingan Rata-rata

Nilai Afektif Siklus 1 dan

Siklus 2

Berdasarkan grafik tersebut bahwa untuk prestasi belajar dari ranah afektif mengalami peningkatan mulai dari siklus 1 yakni 71,66 dan siklus 2 yakni 77,95. Dari hasil tersebut dapat disimpulkan bahwa prestasi siswa pada mata pelajaran Konstruksi Bangunan mengalami peningkatan menjadi lebih baik dengan menggunakan model pembelajaran Kooperatif dengan bantuan inquiry Based Learning.

\section{Ranah Psikomotor}

Hasil penilaian pada ranah psikomotor melalui lembar observasi siswa yang diamati selama proses pembelajaran berlangsung. Berikut adalah aspek yang dinilai dalam penilaian ranah psokomotor: a) Gerakan seluruh badan; b) Gerakan yang terkoordinasi; c) Komunikasi nonverbal; d) Kebolehan dalam berbicara.

Hasil penilaian ranah psikomotor untuk capaian ketuntasan dari tiap siklusnya yang digambarkan dalam grafik pada gambar berikut:

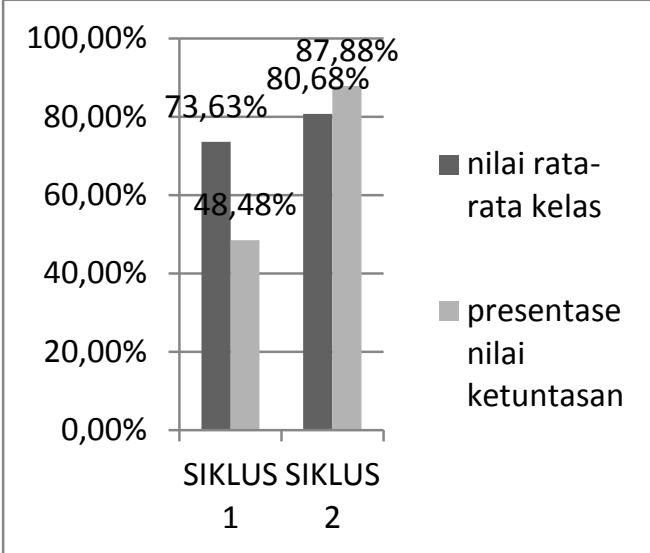

Gambar 3. Grafik Perbandingan Rata-rata

Nilai Psikomotor Siklus 1 dan Siklus 2

Berdasarkan grafik tersebut bahwa untuk prestasi belajar dari ranah psikomotor mengalami peningkatan mulai dari siklus 1 yakni 73,63 dan siklus 2 yakni 80,68. Dari hasil tersebut dapat disimpulkan bahwa prestasi siswa pada mata pelajaran Konstruksi Bangunan mengalami peningkatan menjadi lebih baik dengan menggunakan model pembelajaran Kooperatif dengan bantuan inquiry Based Learning.

\section{Prestasi Belajar Siswa}

Pemahaman siswa terhadap materi pengetahuan bata, ikatan bata dan hubungan bata yang telah dipelajari dapat diketahui dari hasil kognitif, afektif dan psikomotor keseluruhan siklus yang dilaksanakan menggunakan model pembelajaran Kooperatif dengan bantuan inquiry

\footnotetext{
${ }^{1}$ Mahasiswa Program Studi Pendidikan Teknik Bangunan FKIP UNS

${ }^{2}$ Pembimbing I Sri Sumarni, S.T., M.T.

${ }^{3}$ Pembimbing II Sukatiman, S.T.,M.Si.
} 
Based Learning dapat dilihat pada tabel berikut ini:

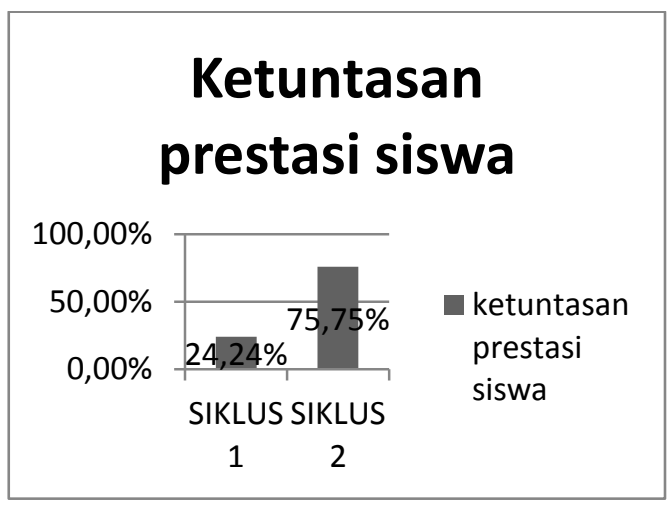

Gambar 3. Grafik Persentase Ketuntasan

Siswa

Berdasarkan grafik tersebut bahwa untuk persentase ketuntasan belajar siswa tiap siklusnya mengalami peningkatan mulai dari siklus 1 yakni $24,24 \%$ dan siklus 2 yakni $75,75 \%$. Dari hasil tersebut dapat disimpulkan bahwa prestasi siswa pada mata pelajaran Konstruksi Bangunan mengalami peningkatan menjadi lebih baik dengan menggunakan model pembelajaran Kooperatif dengan bantuan inquiry Based Learning.

\section{SIMPULAN}

Berdasarkan hasil penelitian tindakan kelas dengan menggunakan model pembelajaran model pembelajaran Kooperatif dengan bantuan inquiry Based Learning pada mata pelajaran Konstruksi Bangunan siswa kelas X TGB 1 SMK Negeri 1
Geneng tahun pelajaran 2015/2016 menunjukkan bahwa:

1. Penerapan model pembelajaran Kooperatif dengan bantuan inquiry Based Learning dapat meningkatkan prestasi siswa pada mata pelajaran Konstruksi Bangunan kelas X TGB 1 SMK Negeri 1 Geneng, yakni sebesar $24,24 \%$ atau 8 siswa dan meningkat menjadi $75,75 \%$ atau 25 siswa yang tuntas.

2. Penerapan model pembelajaran Kooperatif dengan bantuan inquiry Based Learning dapat meningkatkan efektivitas pembelajaran pada kelas X TGB 1 SMK Negeri 1 Geneng pada mata pelajaran Konstruksi Bangunan.

\section{Saran}

Berdasarkan hasil penelitian tindakan kelas yang telah dilaksanakan yang menerapkan model pembelajaran Kooperatif dengan bantuan inquiry Based Learning dapat maksimal apabila:

1. Guru hendaknya lebih inovatif dalam pembelajaran agar siswa

${ }^{1}$ Mahasiswa Program Studi Pendidikan Teknik Bangunan FKIP UNS

${ }^{2}$ Pembimbing I Sri Sumarni, S.T., M.T..

${ }^{3}$ Pembimbing II Sukatiman, S.T.,M.Si. 
dapat menerima materi yang disampaikan dengan baik.

2. Guru hendaknya dalam membagi kelompok saat pembelajaran diskusi secara heterogen agar siswa pandai dan kurang pandai dapat saling interaksi dalam pembelajaran kelompok.

3. Guru hendaknya selalu meningkatkan kemampuan pengelolaan kelas, antara lain membagi waktu dengan baik dalam melaksanakan kegiatan pembelajaran dan memberi perhatian pada siswa yang kurang dalam belajar.

4. Siswa hendaknya bisa lebih mempersiapkan diri sebelum kegiatan pembelajaran di kelas.

5. Siswa hendaknya dapat berperan aktif serta percaya diri menyampaikan pendapat, ide dan pertanyaan di kelas seputar pembelajaran secara tertib dan teratur, sehingga proses pembelajaran dapat berjalan lancar.
6. Penelitian tindakan ini memerlukan waktu yang lama sehingga diperlukan persiapan yang cukup dan waktu yang luang agar pembagian waktu dapat sesuai rencana sehingga penelitian dapat terlaksana dengan baik.

7. Disarankan bagi peneliti di masa yang akan datang untuk mengadakan penelitian sejenis dan relevan dengan penelitian ini dapat mengembangkan lagi dari apa yang ada dalam penelitian ini, sehingga dapat meningkatkan kualitas pembelajaran.

${ }^{1}$ Mahasiswa Program Studi Pendidikan Teknik Bangunan FKIP UNS

${ }^{2}$ Pembimbing I Sri Sumarni, S.T., M.T..

${ }^{3}$ Pembimbing II Sukatiman, S.T.,M.Si. 


\section{DAFTAR PUSTAKA}

Arifin, Zainal. (2014). "Evaluasi

Pembelajaran". Bandung:

Remaja Rosdakarya.

Hamdani, M.A. (2011). "Strategi Belajar Mengajar".

Bandung: Pustaka Setia.

Hamruni. (2012). "Strategi

Pembelajaran".

Yogyakarta: Insan Mandiri.

Isjoni. (2009). "Cooperative Learning

Efektivitas Pembelajaran

Kelompok”. Bandung:

Alfabeta.

Rusman. (2012). "Model-model

Pembelajaran". Jakarta:

Raja Grafindo Persada.

Sutopo, H. B. (2006). "Penelitian

Kualitatif Dasar Teori dan

Terapannya Dalam

Penelitian". Surakarta: Uns

Press.

Uno, Hamzah B. \& Nurdin Mohamad.

(2015). "Belajar dengan
Pendekatan PAILKEM”.

Jakarta: Bumi Aksara.

Metz, A. M. 2008. “Teaching Statistics in Biology: Using Inquirybased Learning to Strengthen Understanding of Statistical Analysis in Biology Laboratory Courses". Department of Cell Biology and Neuroscience, Montana State University, Bozeman, MT 59717.

http://dx.doi.org/10.1187/cb

e.07-07-0046 